\title{
Examination of the Selected Physical and Motoric Characteristics of Students with Special Needs in Turkish Schools Aged 7-14
}

\author{
Rustem Orhan ${ }^{1}$, Murat Ergin ${ }^{2}$, Sinan Ayan ${ }^{3} \&$ Ekrem Boyali ${ }^{4}$ \\ ${ }^{1}$ Physical Education and Sport, Kirikkale University, Kirikkale, Turkey \\ ${ }^{2}$ Kirikkale High School, Kirikkale, Turkey \\ ${ }^{3}$ Physical Education and Sport, Kirikkale University, Kirikkale, Turkey \\ ${ }^{4}$ Physical Education and Sport, Selcuk University, Konya, Turkey \\ Correspondence: Rustem Orhan, Kirikkale University, Physical Education and Sport, Kirikkale, Turkey. E-mail: \\ rorhan@kku.edu.tr
}

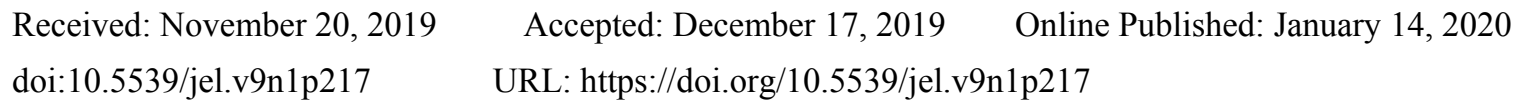

\begin{abstract}
The aim of this paper was to examine the selected physical and motoric characteristics of students with mild intellectual disabilities. The total number of the participants was 119 (54 females and 65 males) and the mean age was $10.78 \pm 1.88$ years. Height, weight, body mass index (BMI), body fat percentage, and body fat mass scores were collected to determine the physical characteristics. Handgrip strength, vertical jump, standing long jump, flexibility, and $20 \mathrm{~m}$ speed running tests were performed to determine the motoric characteristics. The data were analyzed using IBM SPSS 22 package program. Descriptive statistical methods were used in the evaluation of the data. The male students performed better than the female students in all motor performance tests except the flexibility test. The older students performed better, as in the previous studies. Most of the students in the study were found to have a low or normal body mass index. However, according to the literature, children with special needs tend to be overweight and obese due to sedentary lifestyle. One reason for this difference might be a small sample size. Other reasons could be different socio-economic backgrounds and different extracurricular physical activity habits.
\end{abstract}

Keywords: students with special needs, motor characteristics, physical education

\section{Introduction}

It is definitely important to understand the physical and motor development of children with mental disabilities if you want to better identify them, to better identify their needs and to better help them (Yilmaz et al., 2006).

Mental disability is characterized by limitations in mental functions including serious deficiencies or limitations in the individual's cognitive, language, and motor skills as well as in daily activities (Salvador \& Bertelli, 2008) and social skills (Pitetti \& Boneh, 1995; Skowronski et al., 2009).

Today, the term "special needs individuals" is preferred to refer to such children in order to avoid labeling and negatively affecting them by causing a negative attitude. Turkish Ministry of Education (TME, 2000) defines special needs individuals as individuals who, for various reasons, show significant differences in terms of individual characteristics and educational qualifications from their peers with normal development. According to the Ministry of National Education Special Education Services regulation, individuals with intellectual disability are classified as mild, moderate, severe and very severe. An individual with a mild mental disability is defined as an individual with limited need for special and supportive education due to a slight level of insufficiency in cognitive functions as well as in social and adaptive life skills. The "special education class" is defined as a class opened in schools and institutions for students whose conditions require a separate class according to their type of disability, educational performances and characteristics (TME, 2006).

According to the TME 2017-2018 academic year statistics, the number of students in special education classes in primary schools was 23.305 (Male 15.065, Female 8.240) and in secondary schools 22.510 (Male 13.948, Female 8.562) (TME, 2018).

Rarick (1980) stated that the motoric characteristics of children with mild mental disabilities are 2 to 4 years 
behind their normally developed peers. Children with intellectual disabilities show lower performance in strength, endurance, flexibility, motor coordination and aerobic endurance tests (Fernhall \& Pitetti, 2001; Chaiwanichsiri et al., 2000; Graham \& Reid, 2000; Guideti et al., 2010; Skowronski et al., 2009), as well as balance, and speed tests (Rarick et al., 1970) than normal children. It has also been reported that children with mild mental disabilities perform poorly in galloping, jumping, racket hitting and dancing skills (Ayan et al., 2017). Physical activity levels of children with intellectual disabilities were reported to be lower than their peers with normal development (Frey \& Chow, 2006) due to personal, social, environmental (transportation, etc.) and other barriers (economic factors, etc.) (Ayan \& Ergin, 2017). According to Short and Winnick (2005), obesity reflects the presence of large amounts of body fat, expressed as a percentage of total body mass. It is reported that there is a relationship between high body fat values and heart disease in children. It has also been reported that low physical activity level increases obesity (Queralt et al., 2015; Savucu \& Biçer, 2009; Hinckson et al., 2013; Pitetti et al., 2013) and chronic health problems (Rimmer \& Rowland, 2008).

This study was conducted to investigate the selected physical and motoric characteristics of students with special needs aged 7-14.

\section{Method}

\subsection{Study Group}

This study included 119 students with mild intellectual disabilities (SMID), all of whom voluntarily participated from 14 special education classes of Kurıkkale Provincial Directorate of National Education. Before the study, permission was obtained from Kirikkale Provincial Directorate of National Education with the number 12774561-605.01-E.13532211 dated 19/07/2018. Approval was obtained from the Non-Interventional Clinical Research Ethics Committee of Selçuk University Faculty of Sport Sciences with the number E.21319 dated 31/08/2018. "Family Consent Forms" designed in accordance with the requirements of the Ethics Committee were filled out and signed by the parents of the students. Following a 10-minute warm-up, the subjects were tested accompanied by 2 researchers and their teachers.

\subsection{Data Collection Tools}

1) Length: Holtain stadiometer.

2) Body Weight, Body Fat Percentage, Body Fat Mass: Electronic scale integrated into the bioelectric impedance analyzer (Tanita BC-418MA).

3) Flexibility measurements: Sit \& Reach box.

4) Handgrip Strength: Takei dynamometer.

5) Standing Long Jump Test: Non-slip surface, measuring tape.

6) Active Jump Test: Power platform (Smart Jump Fusion Sport, Australian brand) and mat.

7) 20 m Running Test: flat surface, 4 marking cones, timing system (Fusion Sport Smart Speed).

\subsection{Data Collection}

1) Anthropometric Measurements: Anthropometric measurements were taken in an anatomic posture with shorts and t-shirts without shoes. BMI values were compared with BMI Percentile Chart index for growth reference values (5-19 years) published by the World Health Organization (WHO). Accordingly, BMI values were evaluated as "underweight" for less than 5\%, "normal weight" for between 5-85\%, "overweight " for between 85 $95 \%$, and "obese" for 95\% and above (WHO, 2018).

2) Flexibility Test: The subject, sitting on the floor and placing the soles of the feet flat (without shoes) against the test box, reaches forward as far as possible with the palms facing downward and the hands side by side with the knees locked. The subject holds this position for the distance to be recorded. The test is repeated twice and the higher value is recorded (Gunay et al., 2006). Between the attempts, a 1-minute break is given.

3) Handgrip Strength Test: The subject, standing, holds the dynamometer adjusted according to the subject's hand size in the hand to be tested. With the arm straight and at the right angles (10-15 degrees from the shoulder), the subject squeezes the dynamometer with maximum isometric effort. Starting from the dominant hand, the test is applied twice for each hand, and the better results from the two attempts are recorded in $\mathrm{kg}$. The indicator is reset after each attempt (Tamer, 1995). A 1-minute break is given between two attempts for the same hand.

4) Standing Long Jump Test: The subject stands behind a line marked on the ground with feet slightly apart. Swinging the arms and bending the knees to provide a good move, the subject attempts to jump as far as possible landing on both feet. The measurement is taken from take-off line to the nearest point of contact on the landing 
(back of the heels). The test is repeated twice with a 1-minute break between, and the better result is recorded (Zorba, 2001).

5) Active Jump Test: The subject makes a few trials to show that he/she understands the technique and procedure. A vertical jump mat is used for the vertical jump. The subjects squat rapidly from the upright position with their hands on the waist and jump upwards with maximal force. The test is repeated twice with a 1-minute break between attempts and the higher value is recorded in cm (Köklü et al., 2009).

6) Run Test: The subject runs from $1 \mathrm{~m}$ behind the previously marked start line to the finish line at maximum speed. A photocell is placed at the start and finish line Measurements are recorded in seconds. The test is repeated twice and the higher value is recorded. A 10-minute break is given between attempts.

7) Anaerobic Power: Anaerobic power was calculated according to the following formula by using the vertical jump value and body weight. Anaerobic power $(\mathrm{kg} / \mathrm{sec})=\sqrt{ } 4.9 \mathrm{X}$ (Body weight) $\mathrm{X}$ vertical jump distance $(\mathrm{m})$ (Tamer, 2000).

\subsection{Data Analysis}

The data were evaluated in SPSS 22.0 statistical program, using the descriptive statistics (arithmetic mean, standard deviation, percentage, and frequency).

\section{Results}

Table 1. Distribution of participants by age

\begin{tabular}{|c|c|c|c|c|c|c|c|c|c|c|c|c|c|c|c|c|c|c|}
\hline \multirow[t]{2}{*}{ Groups } & \multicolumn{2}{|c|}{7 years } & \multicolumn{2}{|c|}{8 years } & \multicolumn{2}{|c|}{9 years } & \multicolumn{2}{|c|}{10 years } & \multicolumn{2}{|c|}{11 years } & \multicolumn{2}{|c|}{12 years } & \multicolumn{2}{|c|}{13 years } & \multicolumn{2}{|c|}{14 years } & \multicolumn{2}{|c|}{ Total } \\
\hline & $\mathrm{f}$ & $\%$ & $\mathrm{f}$ & $\%$ & $\mathrm{f}$ & $\%$ & $\mathrm{f}$ & $\%$ & $\mathrm{f}$ & $\%$ & $\mathrm{f}$ & $\%$ & $\mathrm{f}$ & $\%$ & $\mathrm{f}$ & $\%$ & $\mathrm{f}$ & $\%$ \\
\hline Female & 5 & 9.3 & 3 & 5.6 & 3 & 5.6 & 11 & 20.4 & 9 & 16.7 & 14 & 25.9 & 7 & 13.0 & 2 & 3.7 & 54 & 45.4 \\
\hline Male & 5 & 7.7 & 2 & 3.1 & 8 & 12.3 & 13 & 20.0 & 10 & 15.4 & 13 & 20.0 & 7 & 10.8 & 7 & 10.8 & 65 & 54.6 \\
\hline Total & 10 & 8.4 & 5 & 4.2 & 11 & 9.2 & 24 & 20.2 & 19 & 16.0 & 27 & 22.7 & 14 & 11.8 & 9 & 7.6 & 119 & 100.0 \\
\hline
\end{tabular}

A total of 119 students participated in the study. The number of male students $54(44.4 \%)$, while 65 of them were female $(54.6 \%)$.

Table 2. Distribution of participants according to BMI classification

\begin{tabular}{lllllllllll}
\hline \multirow{2}{*}{ Groups } & \multicolumn{2}{l}{ Underweight } & Normal & \multicolumn{3}{c}{ Overweight } & \multicolumn{2}{l}{ Obese } & \multicolumn{3}{l}{ Total } \\
\cline { 2 - 11 } & $\mathrm{f}$ & $\%$ & $\mathrm{f}$ & $\%$ & $\mathrm{f}$ & $\%$ & $\mathrm{f}$ & $\%$ & $\mathrm{~F}$ & $\%$ \\
\hline Female & 30 & 55.6 & 12 & 22.2 & 6 & 11.1 & 6 & 11.1 & 54 & 100.0 \\
Male & 33 & 50.8 & 23 & 35.4 & 7 & 10.8 & 2 & 3.1 & 65 & 100.0 \\
Total & 63 & 52.9 & 35 & 29.4 & 13 & 10.9 & 8 & 6.7 & 119 & 100.0 \\
\hline
\end{tabular}

$55.6 \%$ of the female students and $50.8 \%$ of the male students had thin body mass index, while $3.1 \%$ of the male students and $11.1 \%$ of the female students were obese.

Table 3. Values related to the physical and motoric characteristics of the participants

\begin{tabular}{lllllll}
\hline Parameters & \multicolumn{5}{l}{ MEMALE } & \multicolumn{5}{l}{ MALE } \\
\cline { 2 - 7 } & Min & Max & $\mathrm{X} \pm \mathrm{Ss}$ & Min & Max & $\mathrm{X} \pm \mathrm{Ss}$ \\
\hline Age (years) & 7 & 14 & $10.78 \pm 1.88$ & 7 & 14 & $10.89 \pm 1.96$ \\
Height $(\mathrm{cm})$ & 118.0 & 165.0 & $142.89 \pm 12.88$ & 120.0 & 173.0 & $145.91 \pm 13.90$ \\
Weight $(\mathrm{kg})$ & 20.3 & 75.6 & $42.21 \pm 16.41$ & 19.6 & 93.2 & $42.70 \pm 17.35$ \\
BMI $\left(\mathrm{kg} / \mathrm{m}^{2}\right)$ & 13.6 & 35.7 & $20.48 \pm 5.93$ & 12.5 & 38.3 & $19.58 \pm 5.43$ \\
Body Fat Percentage & 2.4 & 53.4 & $25.27 \pm 9.61$ & 5.8 & 51.9 & $21.58 \pm 9.26$ \\
Body Fat Mass (kg) & 1.6 & 33.8 & $12.08 \pm 8.79$ & 1.3 & 52.3 & $10.63 \pm 9.32$ \\
Right-hand grip strength (kg) & 1.2 & 26.0 & $11.44 \pm 6.34$ & 4.2 & 33.9 & $14.20 \pm 5.87$ \\
Left-hand grip strengtth (kg) & 3.0 & 24.4 & $10.41 \pm 5.41$ & 1.1 & 38.6 & $13.07 \pm 6.44$ \\
Flexibility (cm) & 4.0 & 26.0 & $14.06 \pm 6.20$ & 6.0 & 29.0 & $13.37 \pm 7.08$ \\
Vertical Jump (cm) & 6.0 & 24.0 & $12.17 \pm 4.90$ & 4.0 & 26.0 & $15.02 \pm 5.70$ \\
Long Jump (cm) & 11.0 & 110.0 & $50.50 \pm 25.75$ & 6.0 & 148.0 & $66.22 \pm 38.47$ \\
20 m speed run (sn) & 4.4 & 6.7 & $5.15 \pm 0.84$ & 4.1 & 7.0 & $4.95 \pm 0.96$ \\
Anaerobic power (kg.m/sn) & 14.82 & 109.70 & $41.76 \pm 20.05$ & 16.46 & 134.22 & $43.15 \pm 21.7$ \\
\hline
\end{tabular}


Table 3 shows that the male students performed better than the female students in all of the motoric tests except the flexibility test. As can be seen from Table 3, height and body weight values of the male students are higher than those of the female students. The female students have higher values in other physical characteristics (BMI, body fat percentage, body fat mass) than the male students.

Table 4. Physical characteristics of the participants by age

\begin{tabular}{llllllllll}
\hline Variables & Sex & 7 years & 8 years & 9 years & 10 years & 11 years & 12 years & 13 years & 14 years \\
\cline { 3 - 9 } & & $\mathrm{X} \pm \mathrm{Ss}$ & $\mathrm{X} \pm \mathrm{Ss}$ & $\mathrm{X} \pm \mathrm{Ss}$ & $\mathrm{X} \pm \mathrm{Ss}$ & $\mathrm{X} \pm \mathrm{Ss}$ & $\mathrm{X} \pm \mathrm{Ss}$ & $\mathrm{X} \pm \mathrm{Ss}$ & $\mathrm{X} \pm \mathrm{Ss}$ \\
\hline $\mathrm{H}(\mathrm{cm})$ & $\mathrm{F}$ & $121.24 \pm 6.0$ & $127.70 \pm 4.5$ & $128.10 \pm 3.7$ & $140.71 \pm 6.8$ & $143.76 \pm 9.7$ & $152.99 \pm 8.4$ & $152.26 \pm 8.0$ & $146.50 \pm 14.8$ \\
& $\mathrm{M}$ & $127.30 \pm 5.8$ & $127.50 \pm 9.1$ & $131.96 \pm 6.7$ & $138.39 \pm 8.7$ & $152.49 \pm 9.6$ & $151.82 \pm 5.5$ & $162.80 \pm 6.7$ & $157.13 \pm 12.7$ \\
$\mathrm{BW}(\mathrm{kg})$ & $\mathrm{F}$ & $23.34 \pm 2.5$ & $34.97 \pm 24.4$ & $33.03 \pm 13.2$ & $36.55 \pm 12.6$ & $41.82 \pm 16.8$ & $49.51 \pm 12.7$ & $51.43 \pm 16.8$ & $63.55 \pm 14.6$ \\
& $\mathrm{M}$ & $24.16 \pm 3.0$ & $26.20 \pm 6.0$ & $29.51 \pm 9.9$ & $37.38 \pm 10.3$ & $47.71 \pm 13.9$ & $42.78 \pm 11.2$ & $63.53 \pm 17.5$ & $57.46 \pm 23.3$ \\
$\mathrm{BMI}\left(\mathrm{kg} / \mathrm{m}^{2}\right)$ & $\mathrm{F}$ & $15.70 \pm 0.3$ & $21.33 \pm 12.4$ & $19.97 \pm 7.0$ & $19.75 \pm 5.7$ & $19.80 \pm 5.9$ & $21.13 \pm 5.0$ & $21.93 \pm 5.9$ & $29.40 \pm 0.8$ \\
& $\mathrm{M}$ & $16.02 \pm 4.5$ & $16.00 \pm 1.4$ & $16.80 \pm 4.8$ & $19.59 \pm 4.7$ & $20.32 \pm 3.9$ & $18.45 \pm 4.0$ & $24.07 \pm 6.1$ & $22.86 \pm 8.3$ \\
BFP $(\%)$ & $\mathrm{F}$ & $21.56 \pm 1.3$ & $29.67 \pm 20.6$ & $25.90 \pm 15.9$ & $24.85 \pm 8.6$ & $21.67 \pm 11.6$ & $26.65 \pm 7.3$ & $25.66 \pm 9.0$ & $34.45 \pm 7.7$ \\
& $\mathrm{M}$ & $19.06 \pm 5.8$ & $14.10 \pm 11.7$ & $17.86 \pm 7.9$ & $23.01 \pm 8.9$ & $24.06 \pm 7.3$ & $19.80 \pm 7.0$ & $26.21 \pm 12.4$ & $22.29 \pm 14.5$ \\
$\mathrm{BFM}(\mathrm{kg})$ & $\mathrm{F}$ & $4.96 \pm 0.2$ & $13.90 \pm 17.2$ & $9.93 \pm 9.9$ & $9.93 \pm 8.2$ & $11.78 \pm 9.2$ & $13.90 \pm 6.9$ & $14.49 \pm 9.8$ & $22.45 \pm 9.9$ \\
& $\mathrm{M}$ & $5.40 \pm 2.2$ & $4.05 \pm 3.8$ & $6.16 \pm 5.0$ & $9.40 \pm 5.8$ & $12.13 \pm 5.8$ & $9.00 \pm 5.1$ & $19.66 \pm 16.3$ & $15.49 \pm 15.8$ \\
\hline
\end{tabular}

Note. H: Height, BW: Body Weight, BMI: Body Mass Index, BFP: Body Fat Percentage, BFM: Body Fat Mass.

The table displays that there is an increase in height, body weight, and body fat mass values in parallel with age. According to Table 4, the highest values of BMI $\left(29.40 \pm 0.8 \mathrm{~kg} / \mathrm{m}^{2}\right)$, body fat percentage $(34.45 \pm 7.7)$, and body fat mass $(22.45 \pm 9.9 \mathrm{~kg})$ in girls are at the age of 14 , whereas the highest BMI $\left(24.07 \pm 6.1 \mathrm{~kg} / \mathrm{m}^{2}\right)$, body fat percentage (26.21 \pm 12.4$)$, and body fat mass values $(19.66 \pm 16.3 \mathrm{~kg})$ in male students are at the age of 13 .

Table 5. Motoric characteristics of the participants by age

\begin{tabular}{|c|c|c|c|c|c|c|c|c|c|}
\hline \multirow[t]{2}{*}{ Variables } & \multirow[t]{2}{*}{ Sex } & 7 years & 8 years & 9 years & 10 years & 11 years & 12 years & 13 years & 14 years \\
\hline & & $\mathrm{X} \pm \mathrm{Ss}$ & $\mathrm{X} \pm \mathrm{Ss}$ & $\mathrm{X} \pm \mathrm{Ss}$ & $\mathrm{X} \pm \mathrm{Ss}$ & $\mathrm{X} \pm \mathrm{Ss}$ & $\mathrm{X} \pm \mathrm{Ss}$ & $\mathrm{X} \pm \mathrm{Ss}$ & $\mathrm{X} \pm \mathrm{Ss}$ \\
\hline \multirow[t]{2}{*}{ Rhg(kg) } & $\mathrm{F}$ & $8.00 \pm 10.2$ & $5.80 \pm 4.2$ & $13.80 \pm 4.8$ & $8.25 \pm 4.6$ & $12.42 \pm 6.7$ & $13.79 \pm 5.1$ & $14.04 \pm 7.0$ & $12.65 \pm 4.2$ \\
\hline & M & $5.16 \pm 0.9$ & $13.45 \pm 6.4$ & $11.40 \pm 3.8$ & $13.06 \pm 3.7$ & $13.98 \pm 4.2$ & $14.72 \pm 4.5$ & $18.61 \pm 3.9$ & $21.10 \pm 8.6$ \\
\hline \multirow[t]{2}{*}{$\operatorname{Lhg}(\mathrm{kg})$} & $\mathrm{F}$ & $6.22 \pm 6.8$ & $6.00 \pm 0.5$ & $10.57 \pm 5.3$ & $7.25 \pm 2.5$ & $12.44 \pm 5.4$ & $10.20 \pm 4.6$ & $16.47 \pm 4.7$ & $15.65 \pm 0.5$ \\
\hline & M & $7.68 \pm 3.2$ & $13.40 \pm 3.4$ & $8.50 \pm 2.5$ & $11.21 \pm 3.4$ & $12.88 \pm 4.8$ & $11.90 \pm 5.7$ & $19.14 \pm 2.7$ & $21.87 \pm 10.0$ \\
\hline \multirow[t]{2}{*}{ Flexibilty $(\mathrm{cm})$} & $\mathrm{F}$ & $16.40 \pm 3.7$ & $12.00 \pm 6.9$ & $15.67 \pm 8.4$ & $9.55 \pm 3.6$ & $12.44 \pm 8.8$ & $15.79 \pm 5.3$ & $16.57 \pm 5.0$ & $20.00 \pm 5.7$ \\
\hline & M & $16.80 \pm 2.7$ & $9.50 \pm 2.1$ & $14.75 \pm 6.3$ & $15.38 \pm 7.8$ & $11.30 \pm 6.9$ & $12.23 \pm 9.0$ & $11.57 \pm 4.9$ & $13.57 \pm 8.2$ \\
\hline VJ & $\mathrm{F}$ & $14.60 \pm 1.7$ & $10.33 \pm 8.1$ & $13.00 \pm 3.0$ & $8.45 \pm 3.9$ & $12.89 \pm 5.8$ & $13.29 \pm 5.1$ & $13.29 \pm 3.8$ & $13.00 \pm 7.1$ \\
\hline$(\mathrm{cm})$ & M & $20.40 \pm 5.2$ & $17.50 \pm 4.9$ & $14.00 \pm 5.3$ & $11.92 \pm 4.9$ & $15.40 \pm 5.2$ & $15.31 \pm 7.0$ & $14.14 \pm 5.1$ & $17.14 \pm 4.9$ \\
\hline SLJ & $\mathrm{F}$ & $56.40 \pm 33.5$ & $38.67 \pm 19.6$ & $49.33 \pm 22.4$ & $34.27 \pm 21.1$ & $58.33 \pm 22.4$ & $52.57 \pm 25.4$ & $61.86 \pm 31.0$ & $55.00 \pm 35.4$ \\
\hline$(\mathrm{cm})$ & M & $52.60 \pm 11.9$ & $64.50 \pm 31.8$ & $36.38 \pm 10.3$ & $53.54 \pm 39.3$ & $86.30 \pm 44.2$ & $81.38 \pm 38.7$ & $57.00 \pm 31.3$ & $86.43 \pm 44.4$ \\
\hline \multirow[t]{2}{*}{$\mathrm{RT}$ (sn) } & $\mathrm{F}$ & $5.58 \pm 0.5$ & $5.53 \pm 0.3$ & $5.32 \pm 1.3$ & $5.64 \pm 0.6$ & $5.18 \pm 0.7$ & $4.31 \pm 0.5$ & $5.41 \pm 1.0$ & $5.24 \pm 0.8$ \\
\hline & M & $5.30 \pm 0.7$ & $4.52 \pm 0.4$ & $5.25 \pm 0.8$ & $5.30 \pm 1.1$ & $5.18 \pm 1.0$ & $4.44 \pm 0.7$ & $5.21 \pm 0.9$ & $4.20 \pm 1.0$ \\
\hline $\mathrm{AP}$ & F & $19.76 \pm 3.2$ & $26.62 \pm 15.2$ & $26.79 \pm 13.6$ & $43.06 \pm 18.9$ & $40.99 \pm 16.5$ & $52.04 \pm 24.2$ & $47.81 \pm 15.0$ & $87.23 \pm 25.4$ \\
\hline$(\mathrm{kgm} / \mathrm{sn})$ & $\mathrm{M}$ & $23.71 \pm 1.6$ & $23.70 \pm 2.1$ & $35.08 \pm 25.6$ & $41.35 \pm 21.9$ & $46.11 \pm 16.6$ & $54.55 \pm 31.0$ & $51.61 \pm 14.1$ & $51.59 \pm 20.8$ \\
\hline
\end{tabular}

Note. Rhg: Right-hand grip, Lhg: Left-hand grip, VJ: Vertical Jump, SLJ: Standing Long Jump, RT: 20 m Run Test, AP: Anaerobic Power.

Table 5 shows that the female students exhibited the lowest right-hand grip strength at 8 years $(5.80 \pm 4.2 \mathrm{~kg})$ and the male students at 7 years $(5.16 \pm 0.9 \mathrm{~kg})$, while the 13-year-old female students $(14.04 \pm 7.0 \mathrm{~kg})$ and the 14-year-old male students $(21.10 \pm 8.6 \mathrm{~kg})$ had the highest values in right-hand grip strength.

The table also reveals that the male students reached the highest vertical jump $(20.40 \pm 5.2 \mathrm{~cm})$ performance at the age of 7 years. The female students showed the highest anaerobic power performance at the age of 14 (87.23 $\pm 25.4 \mathrm{~kg} / \mathrm{sec})$. 


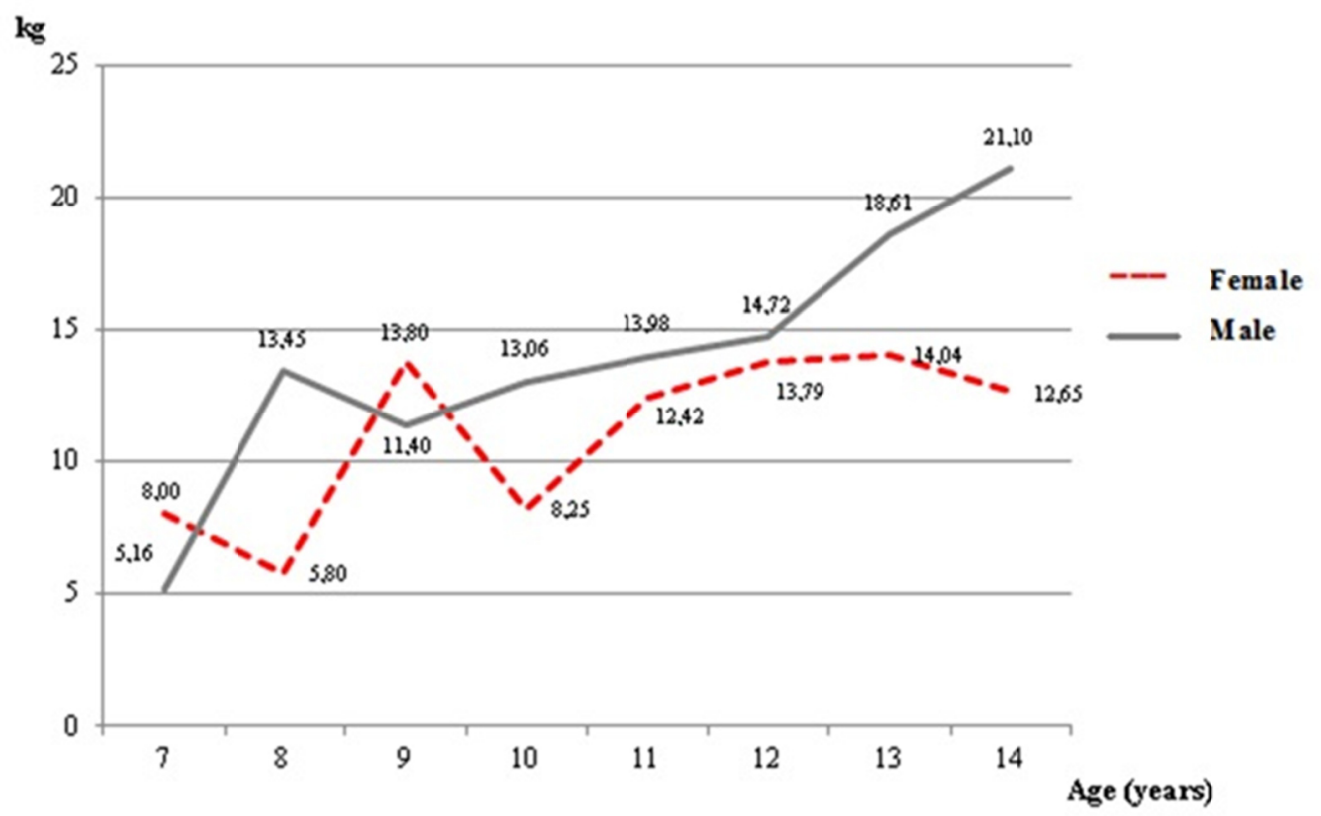

Figure 1. Right-hand grip strength values by age

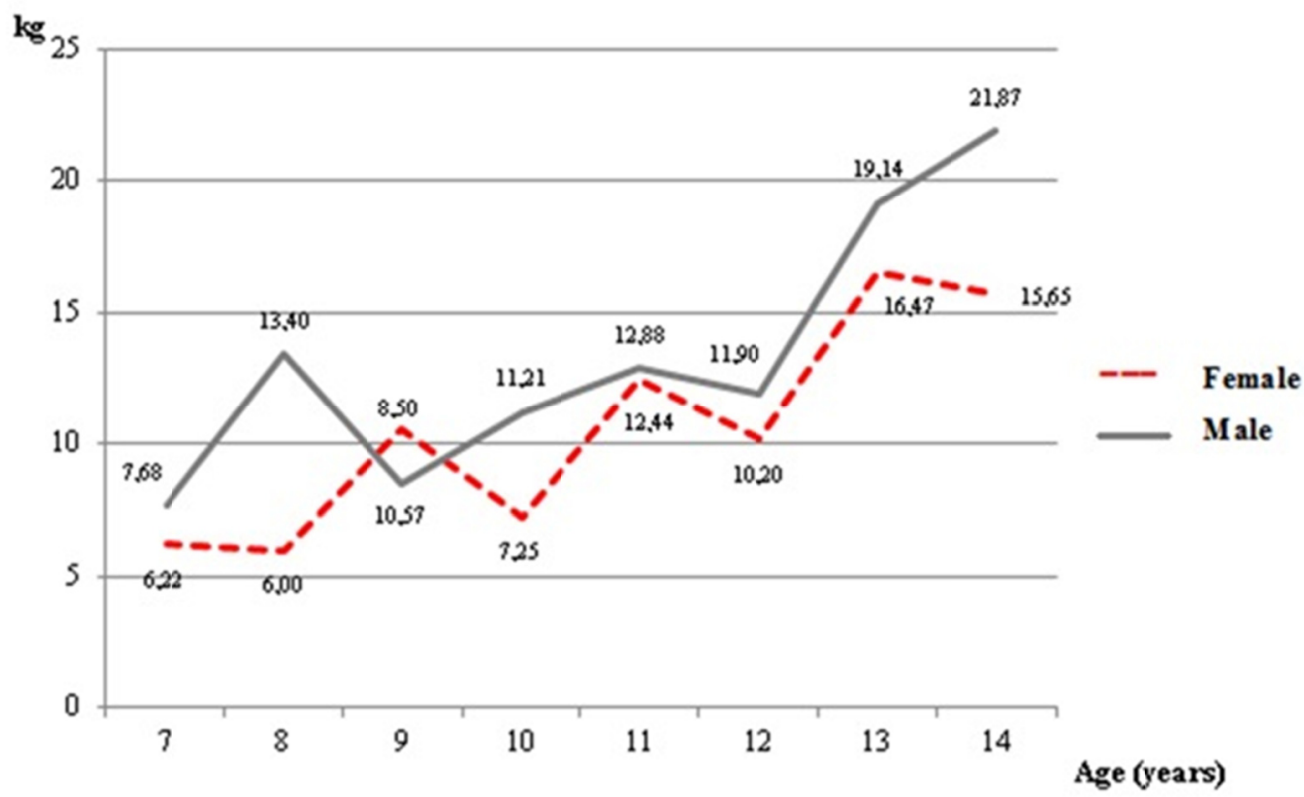

Figure 2. Left-hand grip strength values by age

Figures 1 and 2 reveal that the right-hand grip strength values of girls of 7 and 9 years of age are higher than those of male students of the same age. The figures reflect that in the other age groups, the handgrip strength values of the male students are higher. The left-hand grip strength values of the female students are higher only at age 9. 


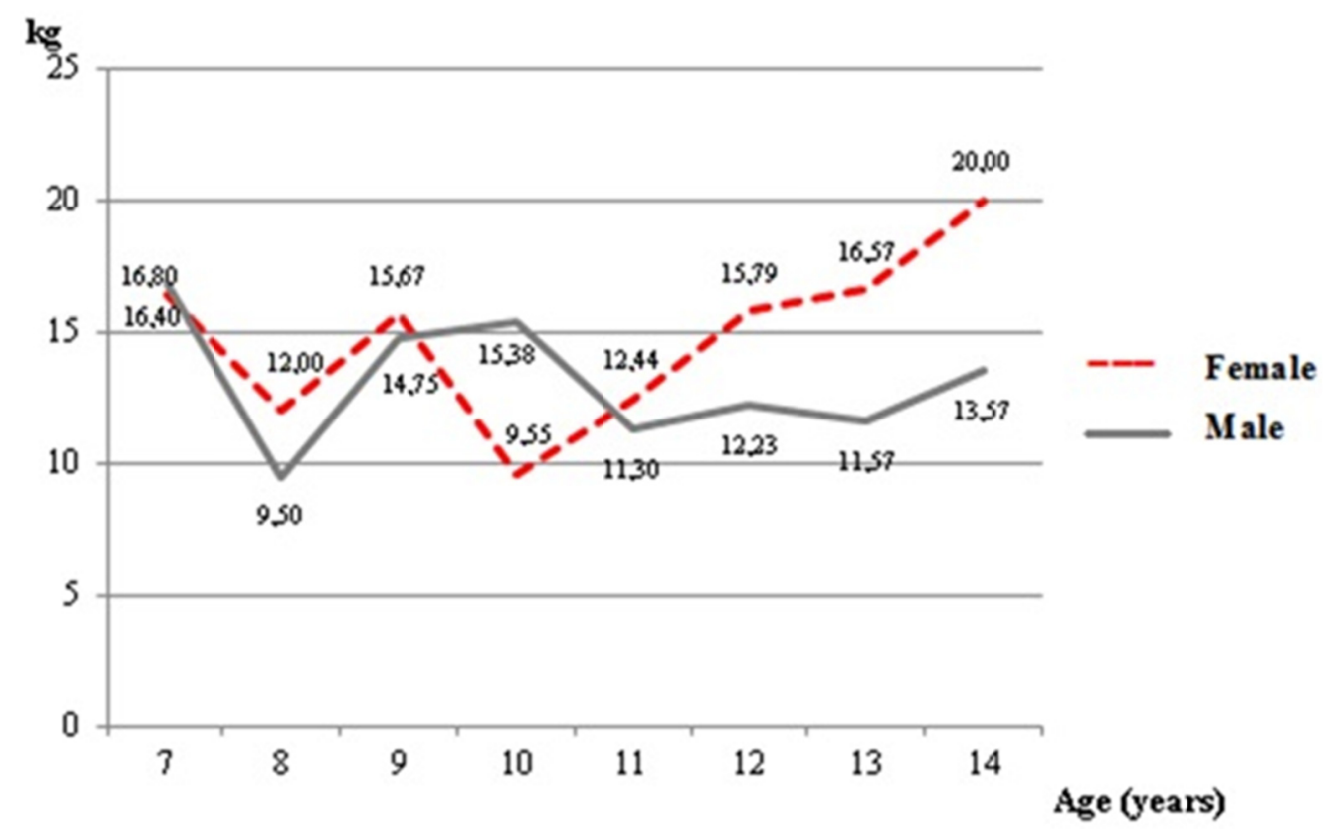

Figure 3. Flexibility test values by age

According to Figure 3, the lowest flexibility values were found in female students at the age of $10(9.55 \pm 3.6 \mathrm{~cm})$ and in male students at the age of $8(9.50 \pm 2.1 \mathrm{~cm})$, while the highest flexibility values were determined in female students at the age of $14(20.00 \pm 5.7 \mathrm{~cm})$ and in male students at the age of $7(16.80 \pm 2.7 \mathrm{~cm})$.

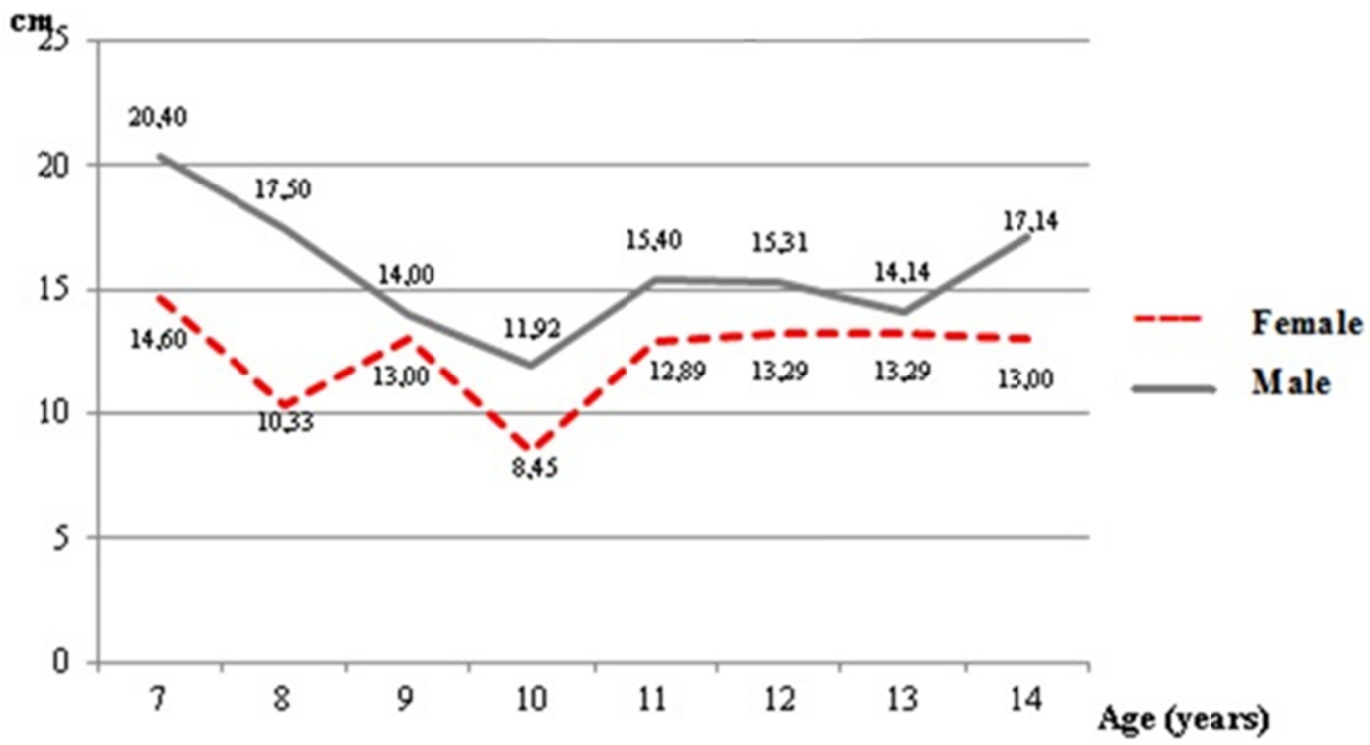

Figure 4. Vertical jump test values by age

When Figure 4 is analyzed, it reveals that the participants exhibited the lowest vertical jump values at the age of 10 (Female: $8.45 \pm 3.9 \mathrm{~cm}$; Male: $11.92 \pm 4.9 \mathrm{~cm}$ ). The figure shows that the highest vertical jump performances of the participants were achieved at 7-year-olds (Female: $14.60 \pm 1.7 \mathrm{~cm}$; Male: $20.40 \pm 5.2 \mathrm{~cm}$ ). 


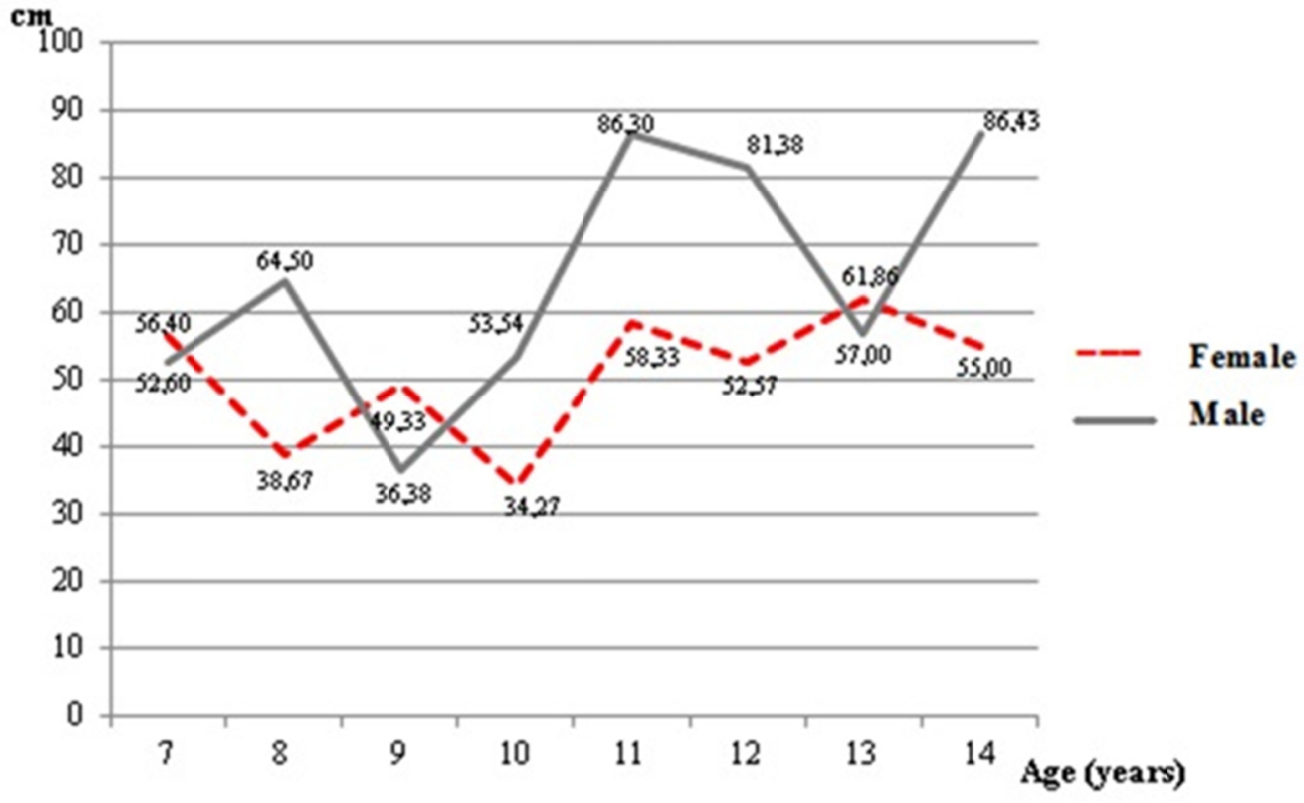

Figure 5. Standing long jump test values by age

Figure 5 shows that the female students had the highest standing long jump values at $13(61.86 \pm 31.0 \mathrm{~cm})$, while the male students reached the maximum values at the age of $14(86.43 \pm 44.4 \mathrm{~cm})$. The lowest standing long jump values were observed in female students at the age of $10(34.27 \pm 21.1 \mathrm{~cm})$ and in male students at the age of $9(36.38 \pm 10.3 \mathrm{~cm})$.

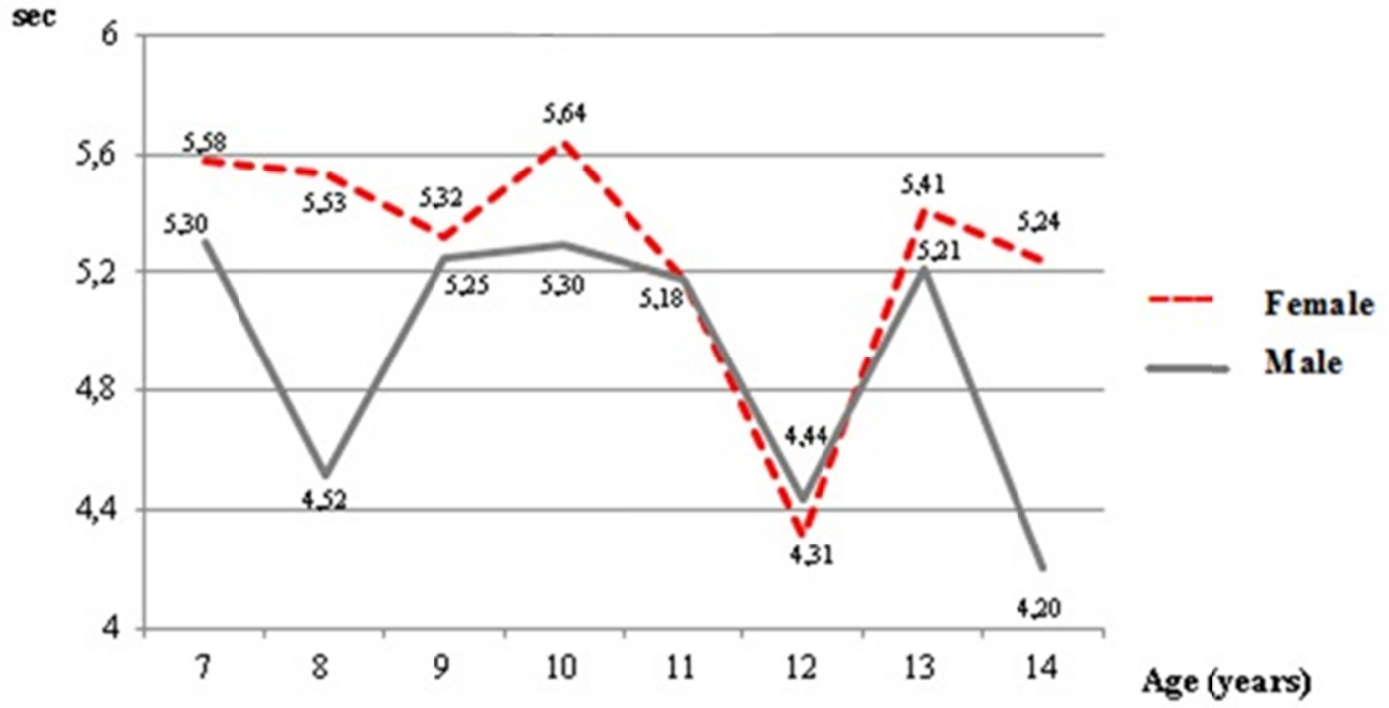

Figure $6.20 \mathrm{~m}$ speed running test values by age

Figure 6 reveals that the female students show the best speed running performance at $12(4.31 \pm 0.5$ seconds $)$ and male students at 14 years $(4.20 \pm 1.0$ seconds). The slowest speed running performance in the female students appeared at the age of $10(5.30 \pm 1.1 \mathrm{sec})$, while in the male students the worst performances emerged at the age of $7(5.30 \pm 0.7 \mathrm{sec})$ and at the age of $10(5.30 \pm 1.1 \mathrm{sec})$. 


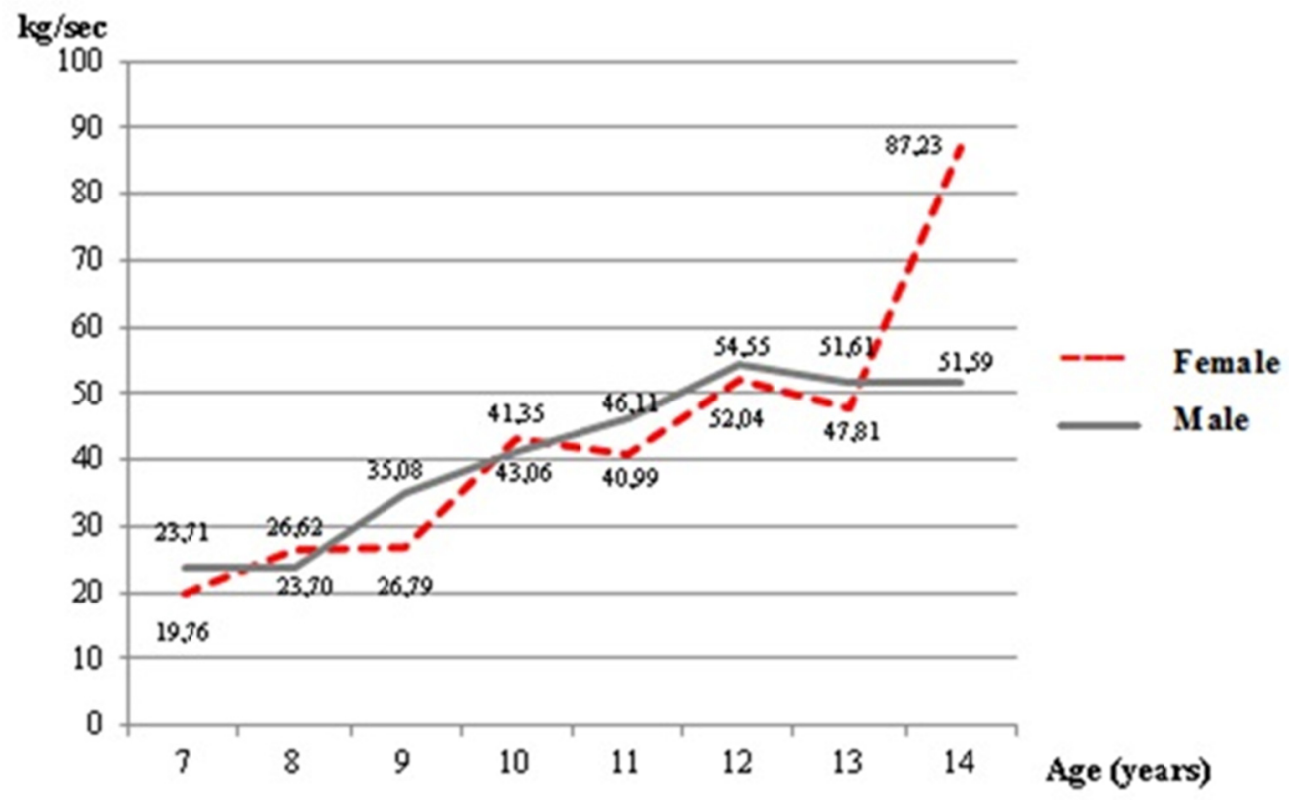

Figure 7. Anaerobic power values by age

Figure 7 shows that anaerobic power increases with age. The female students had the best anaerobic power performance at the age of $14(87.23 \pm 25.4 \mathrm{~kg} / \mathrm{sec})$ and male students at the age of $12(54.55 \pm 31.0 \mathrm{~kg} / \mathrm{sec})$, while the female students had the lowest anaerobic power performance at the age of $7(19.76 \pm 3.2 \mathrm{~kg} / \mathrm{sec})$ and the male ones at the age of $8(23.70 \pm 2.1 \mathrm{~kg} / \mathrm{sec})$.

\section{Discussion}

The aim of this study was to determine the selected physical and motoric characteristics of students with special needs aged 7-14. The study produced mostly similar results to the previous ones in the literatüre. However, there were also differences which can be attributed to the physical activity habits and play facilities of the students participating in this study, time differences in adolescence, socio-economic differences, motivational factors for the test or other characteristics of the sample group.

The arithmetic mean and standard deviation values of the ages of the students were $10.78 \pm 1.88$ years for the female students and $10.89 \pm 1.96$ for the male years. Body weights of the female students were found to be 2.21 $\pm 16.4 \mathrm{~kg}$ and of the male students $42.70 \pm 17.4 \mathrm{~kg}$. The findings obtained from the studies conducted with similar sample groups in the literature are in parallel with this study (Schott \& Holfelder, 2015; Pitetti et al., 2001; Frey \& Chow, 2006; Berktaş et al., 2011; Karahan et al., 2007).

Atan et al. (2016) conducted a study with educable mentally disabled children aged $10.25 \pm 1.60$ years. The body weight findings of those children were higher than the body weight values of the children in this study.

The body weight values of educable intellectually disabled children in the studies (with similar age groups) conducted by Aygün (2004), Özer et al. (1999), Bayazit et al. (2007) and Biçer et al. (2004) were lower than the body weight values obtained in this study.

The height values determined in this study were $142.89 \pm 12.3 \mathrm{~cm}$ for the female students and $145.9 \pm 13.9 \mathrm{~cm}$ for the male students. The height values obtained from similar studies with similar sample groups are in parallel with the findings obtained in this study (Özer et al., 1999; Schott \& Holfelder, 2015; Pitetti et al., 2001; Izquierdo-Gomez et al., 2015; Frey \& Chow, 2006; Berktaş et al., 2011).

In a study conducted by Karahan et al. (2007) with 14-year-old educable intellectually disabled children and in the study conducted by Aygün (2004), the height values were higher than the height values obtained from this study.

However, the height values obtained from studies conducted by Bayazit et al. (2007) and Atan et al. (2016) were found to be lower than the height values obtained in this study.

In the study conducted by Pitetti et al. (2017) with mentally disabled children of 8-14 years of age, the height values of 8 and 9 years old children were in parallel with the findings obtained in our study. However, the height 
values of 10-14-year-old children were higher than the height values obtained in the present study.

The BMI values of the female students participating in this study were $20.48 \pm 5.9 \mathrm{~kg} / \mathrm{m}^{2}$ and of the male students were $19.58 \pm 5.4 \mathrm{~kg} / \mathrm{m}^{2}$. That is, more than $75 \%$ of the participants were "thin" and "normal". There is a general belief that the prevalence of obesity is higher in individuals with intellectual disabilities than in individuals with normal development (Kelly et al., 1987). However, the BMI results obtained in the study do not overlap with this widespread belief.

Izquierdo-Gomez et al. (2015) conducted a study with individuals with Down syndrome and found the BMI value of the male participants $23.60 \mathrm{~kg} / \mathrm{m}^{2}$ and of the girls $24.10 \pm 3.74 \mathrm{~kg} / \mathrm{m}^{2}$. The rate of obesity was found to be $38 \%$ and $28 \%$ in females and males with mild and moderate mental disabilities, respectively (Fernhall, 1993). In women and men with severe and very severe mental disabilities, the obesity rate was found to be $28 \%$ and $7 \%$ respectively (Chaiwanichsiri et al., 2000). Takeuchi (1994) conducted a study in order to determine the rate of obesity in Japanese children with intellectual disabilities found the incidence of obesity $12 \%$. The prevalence of obesity in mentally disabled girls was reported to be more likely than boys, which is similar to the results in our study. It was also reported that obesity rate is higher among secondary school students (12-17 years) than primary school students (6-11 years). In addition, Frey and Chow (2006) reported that $20 \%$ of the participants in their study were obese according to BMI classification. The BMI values obtained in the present study were lower than the BMI values obtained in the studies above.

There are other studies in the literature conducted with similar sample groups providing similar BMI values to the results obtained in this study (Frey \& Chow, 2006; Berktaş et al., 2011; Kubilay et al., 2011; Pitetti et al., 2001; Schott \& Holfelder, 2015; Ün et al., 2004).

The findings obtained in the present study showed that the body fat percentages of the female and male students were $25.27 \pm 9.61$ and $21.58 \pm 9.26$, respectively. In a previous study by Biçer et al. (2004), body fat percentages of female and male students were determined as $22.75 \pm 1.41$ and $20.49 \pm 1.42$, respectively. Ün et al. (2004) established a physical fitness training program for children with mild and moderate mental disabilities and examined the effect of this program on the physical fitness parameters of these children. In the study, body fat percentage of the test group was $18.08 \pm 6.80$; while it was $17.24 \pm 5.85$ for the control group. These results do not overlap with the findings obtained in our study.

In this study, the standing long jump values were $50.50 \pm 25.75 \mathrm{~cm}$ for the female students and $66.22 \pm 38.5 \mathrm{~cm}$ for the male students. Biçer et al. (2004) found similar values in the standing long jump $(39.95+4.23 \mathrm{~cm})$.

The standing long jump values obtained by Aygün (2004) and Karahan et al. (2007) differ from the findings obtained from this study, yielding higher values than our findings.

The flexibility values of the female and male students participating in this study were found to be $14.06 \pm 6.2 \mathrm{~cm}$ and $13.37 \pm 7.1 \mathrm{~cm}$, respectively. In a study conducted by Giagazoglou et al. (2013) with moderate mentally disabled children aged $10.3 \pm 1.6$ years and in another study by Atan et al. (2016) the flexibility performance values were similar to the findings obtained in this study.

However, Frey and Chow (2006) and Karahan et al. (2007) found higher flexibility values, while Kubilay et al. (2011) reported lower flexibility values for mild mentally handicapped individuals (13-14 years of age).

While the right and the left-hand grip strength values of the female students were $11.44 \pm 6.3 \mathrm{~kg}$ and $10.41 \pm 5.4$ $\mathrm{kg}$, respectively, the right and left-hand grip strength values of the male students were $14.20 \pm 5.9 \mathrm{~kg}$ and 13.07 $\pm 6.4 \mathrm{~kg}$ respectively in this study. Berktaş et al. (2011) and Biçer et al. (2004) found lower hand grip strength values, which do not overlap with our findings.

Hartman et al. (2015) and Kubilay et al. (2011) reported higher handgrip strength values than the hand grip strength findings obtained in our study. However, Hartman et al. (2015) reported that an increase in age came with an increase in handgrip strength values in children with mild intellectual disabilities aged 8-12. This result is consistent with our findings.

The vertical jump test values of the female and male students participating in our study were $12.17 \pm 4.9 \mathrm{~cm}$ and $15.02 \pm 5.7 \mathrm{~cm}$, respectively. Berktaş et al. (2011), Atan et al. (2016) and Biçer et al. (2004) obtained higher vertical jump test values, while Giagazoglou et al. (2013) reported similar vertical jump values $(12.89 \pm 6.25 \mathrm{~cm})$ to our findings.

Our study revealed that speed run test values of the female students were $5.15 \pm 0.8 \mathrm{sec}$ while the same values for the male students were $4.95 \pm 1.0 \mathrm{sec}$. However, Atan et al. (2016) reported lower speed values while Aygün (2004) indicated higher values than the findings obtained in this study. 


\section{Conclusion}

More detailed data on the physical and motor performances of children with special needs can provide useful information for physical education teachers, coaches and parents to help develop motor intervention programs. In future work, studies with larger sample groups can be conducted. The physical and motoric characteristics of students with special needs can be compared with normally developed children or children with different disabilities.

\section{Acknowledgments}

A part of this study was presented as a verbal presentation at the 16th International Sports Science Congress held in Antalya between 31 October-03 November 2018. Any grants or other financial support was not received for our study. We thanks Kırıkkale Provincial Directorate of National Education, students and parents for their support. All procedures performed in this study were in accordance with ethical standards of the institutional and/or national research committee and with the 1964 Helsinki declaration and its later amendments or comparable ethical standards. No conflict of interest has been declared.

\section{References}

Atan, T., Eliöz, M., Çebi, M., Ünver, Ş., \& Atan, A. (2016). Basketbol antrenmanının eğitilebilir zihinsel engelli çocukların motorik özelliklerine etkisinin incelenmesi. Spor ve Performans Araştırmaları Dergisi, 7(1), 29 35. https://doi.org/10.17155/spd.78754

Ayan, S., \& Ergin, M. (2017). Özel gereksinimli bireylerin fiziksel aktivite programlarına katılımlarını engelleyen faktörlerin incelenmesi. Turkish Studies, 12(25), 149-168. https://doi.org/10.7827/TurkishStudies.12231

Ayan, S., Ergin, M., \& Alıncak, F. (2017). The evaluation of the participation of game and physical education lesson of the mild severe degree mental retardation and autistic students. European Journal of Special Education Research, 2(2), 35-49. ISSN: 2501-2428.

Aygün, Ö. (2004). Zihinsel Engelli Çocukların Egzersiz Öncesi ve Sonrasl Motorik Performanslarının Karşılaştırılması. Yüksek Lisans Tezi. Beden Eğitimi ve Spor Öğretmenliği Ana Bilim Dalı. Sakarya Üniversitesi Sosyal Bilimler Enstitüsü.

Bayazıt, B., Meriç, B., Aydın, M., \& Seyrek, E. (2007). Eğitilebilir zihinsel engelli çocuklarda eğlenceli atletizm antrenman programının psikomotor özelliklere etkisi. Spormetre Beden Eğitimi ve Spor Bilimleri Dergisi, 5(4), 173-176. https://doi.org/10.1501/Sporm_0000000088

Berktaş, N., Yanardağ, M., Yılmaz, İ., Aras, Ö., Konukman, F., \& Boyacı, A. (2011). The effects of inclusion class programmes on physical fitness for children with mental challenges. Developmental Neurorehabilitation, 14(6), 389-393. https://doi.org/10.3109/17518423.2011.623141

Biçer, Y., Savucu, Y., Kutlu, M., Kaldırımcı, M., \& Pala, R. (2004). Güç ve kuvvet egzersizlerinin zihinsel engelli çocukların hareket beceri ve yeteneklerine etkisi. Doğu Anadolu Bölgesi Araştırmaları, 3(1), 173179 .

Chaiwanichsiri, D., Sanguanrungsirikul, S., \& Suwannakul, W. (2000). Poor physical fitness of adolescents with mental retardation at Rajanukul School, Bangkok. Journal of the Medical Association Thailand, 83(11), $1387-1392$.

Fernhall, B. (1993). Physical fitness and exercise of individual with mental retardation. Medicine Science in Sports Exercise, 25(4), 442-450. https://doi.org/10.1249/00005768-199304000-00006

Fernhall, B., \& Pitetti, K. H. (2001). Limitations to physical work capacity in individuals with mental retardation. Clinical Exercise Physiologist, 3, 176-185.

Frey, G. C., \& Chow, B. (2006). Relationship between bmi, physical fitness, and motor skills in youth with mild intellectual disabilities. International Journal of Obesity, 30, 861-867. https://doi.org/10.1038/sj.ijo.0803196

Giagazoglou, P., Kokaridas, D., Sidiropoulou, M., Patsiaouras, A., Karra, C., \& Neofotistou, K. (2013). Effects of a trampoline exercise intervention on motor performance and balance ability of children with intellectual disabilities. Research in Developmental Disabilities, 34, 2701-2707. https://doi.org/10.1016/j.ridd.2013.05.034

Graham, A., \& Reid, G. (2000). Physical fitness of adults with an intellectual disability: A 13-year follow-up study. Research Quarterly for Exercise and Sport, 71(2), 152-161. https://doi.org/10.1080/02701367.2000.10608893 
Guideti, L., Franciosi, E., Gallota, M. C., Emeranziani, G. P., \& Baldari, C. (2010). Could sport specialization influence fitness and health of adults with mental retardation? Research in Developmental Disabilities, 5 , 1070-1075. https://doi.org/10.1016/j.ridd.2010.04.002

Günay, M., Tamer, K., \& Cicioğlu, I. (2006). Spor Fizyolojisi ve Performans Ölçümleri. Ankara: Gazi Kitabevi.

Hartman, E., Smith, J., Westendorp, M., \& Visscher, C. (2015). Development of physical fitness in children with intellectual disabilities. Journal of Intellectual Disability Research, 59(5), 439-449. https://doi.org/10.1111/jir.12142

Hinckson, E. A., Dickinson, A., Water, T., Sands, M., \& Penman, L. (2013), Physical activity, dietary habits and overall health in overweight and obese children and youth with intellectual disability or autism. Research in Developmental Disabilities, 34, 1170-1178. https://doi.org/10.1016/j.ridd.2012.12.006

Izquierdo-Gomez, R., Martinez-Gomez, D., Villagra, A., Fernhall, B., \& Veiga, O. L. (2015). Associations of physical activity with fatness and fitness in adolescents with down syndrome: The up\&down study. Research in Developmental Disabilities, 36, 428-436. https://doi.org/10.1016/j.ridd.2014.10.022

Karahan, M., Demir, R., Şahin, I., \& Süel, E. (2007). Eğitilebilir zihinsel engelli erkek çocukların bazı motor becerilerine antrenmanın etkisi. Niğde Üniversitesi Beden Eğitimi ve Spor Bilimleri Dergisi, 1(2), 71-75.

Kelly, L. E., Rimmer, J. H., \& Ness, R. A. (1987). A practical method for estimating percent body fat of mentally retarted adults. Adapted Physical Activity Quarterly, 3, 167-176. https://doi.org/10.1123/apaq.3.2.167

Köklü, Y., Özkan, A., Alemdaroğlu, U., \& Ersöz, G. (2009). Genç futbolcuların bazı fiziksel uygunluk ve somatotip özelliklerinin oynadıkları mevkilere göre karşılaştırılması. Spormetre Beden Eğitimi ve Spor Bilimleri Dergisi, 7(2), 61-68. https://doi.org/10.1501/Sporm_0000000151

Kubilay, N. S., Yıldırım, Y., Kara, B., \& Akdur, H. H. (2011). Effect of balance training and posture exercises on functional level in mental retardation. Fizyoterapi Rehabilitasyon, 22(2), 55-64.

Milli Eğitim Bakanlı̆̆ı Özel Eğitim Hizmetleri Yönetmeliği. (2006). Retrieved from https://orgm.meb.gov.tr/meb_iys_dosyalar/2012_10/10111226_ozel_egitim_hizmetleri_yonetmeligi_son.pd $\mathrm{f}$

Özer, D., Aral, N., Özer, K., \& Güvenç, A. (1999). Eğitilebilir zihinsel engelli çocukların fiziksel özelliklerinin normal gelişim gösteren yaşıtları ile karşılaştırılarak incelenmesi. Beden Eğitimi ve Spor Bilimleri Dergisi, $3,1-17$.

Pitetti, K., Baynard, T., \& Agiovlasitis, S. (2013). Children and adolescents with down syndrome, physical fitness and physical activity. Journal of Sport and Health Science, 2, 47-57. https://doi.org/10.1016/j.jshs.2012.10.004

Pitetti, K., Miller, R. A., \& Loovis, M. (2017). Balance and coordination capacities of male children and adolescents with intellectual disability. Adapted Physical Activity Quarterly, 34, 1-18. https://doi.org/10.1123/APAQ.2016-0010

Pitetti, K. H., \& Boneh, S. (1995). The relationship between cardiovascular fitness (PeakVO2) and isokinetic leg strength in adults with mental retardation. Medicine and Science in Sports and Exercise, 27, 423-428. https://doi.org/10.1249/00005768-199503000-00020c

Pitetti, K. H., Yarmer, D. A., \& Fernhall, B. (2001). Cardiovascular fitness and composition of youth with and without mental retardation. Adapted Physical Activity Quarterly, 18, 127-141. https://doi.org/10.1123/apaq.18.2.127

Queralt, A., Vicente-Ortiz, A., \& Molina-Garcia, J. (2015). The physical activity patterns of adolescents with intellectual disabilities: A descriptive study. Disability and Health Journal, 9, 341-345. https://doi.org/10.1016/j.dhjo.2015.09.005

Rarick, G. L. (1980). Cognitive-motor relationships in the growing years. Research Quarterly for Exercise and Sport, 51, 174-192. https://doi.org/10.1080/02701367.1980.10609282

Rarick, G. L., Widdop, J. H., \& Broadhead, G. D. (1970). Physical fitness and motor performance of educable mentally disabled children. Exceptional Children, 36, 509-519. https://doi.org/10.1177/001440297003600704

Rimmer, J. A., \& Rowland, J. L. (2008). Physical activity for youth with disabilities: A critical need in an 
underserved population. Developmental Neurorehabilitation, 11, 141-148. https://doi.org/10.1080/17518420701688649

Salvador, L., \& Bertelli, M. (2008). Mental retardation or intellectual disability: Time for a conceptual change. Psychopathology, 41, 10-16. https://doi.org/10.1159/000109950

Savucu, Y., \& Biçer, S. Y. (2009). Zihinsel engellilerde fiziksel aktivitelerin önemi. Türkiye Klinikleri Journal of Sports Sciences, 1(2), 117-122.

Schott, N., \& Holfelder, B. (2015). Relationship between motor skill competency and executive function in children with Down's syndrome. Journal of Intellectual Research, 59(9), 860-872. https://doi.org/10.1111/jir.12189

Short, F. X., \& Winnick, J. P. (2005). Test items and standards related to body composition on the Brockport physical fitness test. Adapted Physical Activity Quarterly, 22, 356-370. https://doi.org/10.1123/apaq.22.4.356

Skowronski, W., Horvat, M., Nocera, J., Roswal, G., \& Croce, R. (2009). Eurofit special: European fitness battery score variation among individuals with intellectual disabilities. Adapted Physical Activity Quarterly, 26(1), 54-67. https://doi.org/10.1123/apaq.26.1.54

Takeuchi, E. (1994). Incidence of obesity among school children with mental retardation in Japan. American Journal of Mental Retardation, 99, 283-288.

Tamer, K. (1995). Kuvvet, Maksimal Aerobik Güç, Maksimal Anaerobik Güç. Sporda Fiziksel-Fizyolojik Performansın Ölçülmesi ve Değerlendirilmesi (1. Baskı). Ankara: Türkerler Kitabevi.

Tamer, K. (2000). Sporda Fiziksel Fizyolojik Performansın Ölçülmesi ve Değerlendirilmesi (2. Basım). Ankara: Bağırgan Yayınevi.

TME. (2000). Milli Eğitim Bakanlığı Özel Eğitim Hizmetleri Yönetmeliği.18.01.2000 tarih 23937 sayılı Resmi Gazete. Retrieved June 01, 2018, from http://mevzuat.meb.gov.tr/html/66.html

TME. (2018). Milli Ĕgitim İstatistikleri Örgün Eğitim 2017/2018. Retrieved March 11, 2019, from https://sgb.meb.gov.tr/meb_iys_dosyalar/2018_09/06123056_meb_istatistikleri_orgun_egitim_2017_2018. pdf

Ün, N., Erbahçeci, F., \& Ergun, N. (2004). Zihinsel özürlü çocuklarda fiziksel uygunluk eğitim programının fiziksel uygunluk düzeyleri üzerine etkisi. Fizyoterapi Rehabilitasyon, 15(3), 107-113.

WHO. World Health Organization. (2016). BMI for age boys 5 to 19 years percentiles. Retrieved May 6, 2018, from http://www.who.int/growthref/bmifa_boys_5_19, years_per.pdf

Yılmaz, G., Sevindi, T., İbiş, S., Yılmaz, B., \& Kestek, S. (2006). 10-14 yaş grubu öğretilebilir zihinsel engellilerde makro dönem esneklik antrenman sonucu gelişmelerin incelenmesi. Selçuk Üniversitesi Beden Ĕgitimi ve Spor Bilim Dergisi, 8(1-2), 1-4.

Zorba, E. (2001). Fiziksel Uygunluk. İkinci Baskl. Ankara: Gazi Kitabevi Tic. Ltd. Şti.

\section{Copyrights}

Copyright for this article is retained by the author, with first publication rights granted to the journal.

This is an open-access article distributed under the terms and conditions of the Creative Commons Attribution license (http://creativecommons.org/licenses/by/4.0/). 